\title{
Chapter 2: Russia's Development as a Top Player in World Grain Trade
}

\author{
William M. Liefert and Olga Liefert
}

\section{INTRODUCTION}

Since the mid-2000s, Russia has developed into a major grain exporter. The growth in grain exports in the last few years was especially high, with foreign sales rising from the 2011-2015 period to the 2016-2019 period by an annual average of 64 percent, from 27 to 44 million metric tonnes (mmt). The country's main grain export is wheat, and by the late $2010 \mathrm{~s}$

The authors thank Steven Zahniser for helpful comments. The findings and conclusions in this chapter are those of the authors and should not be construed to represent any official USDA or U.S. Government determination or policy. The research in this article was supported by the intramural research programme of the U.S. Department of Agriculture, Economic Research Service

\footnotetext{
W. M. Liefert $(\otimes)$. O. Liefert

Economist, Market and Trade Economics Division of the Economic Research Service, United States Department of Agriculture, Washington, DC, USA e-mail: wliefert@ers.usda.gov

O. Liefert

e-mail: Olga.Liefert@usda.gov

(C) The Author(s) 2022

S. K. Wegren and F. Nilssen (eds.), Russia's Role in the Contemporary

International Agri-Food Trade System, Palgrave Advances

in Bioeconomy: Economics and Policies,

https://doi.org/10.1007/978-3-030-77451-6_3
} 
Russia's annual average foreign sales of $35 \mathrm{mmt}$ gave the country around a 20 percent share in world wheat trade.

During the late Soviet period, Russia (along with the Soviet Union as a whole) was a major grain importer rather than exporter. This chapter examines how Russia has flipped its trade balance in grain and emerged as a large wheat exporter. The key causal developments were the extreme downsizing of the country's livestock sector during the 1990s which reduced domestic demand for feed grain, and more importantly, the steady rise in grain production beginning after 2000 that created surpluses for export. The growth in Russian grain output has been driven by an increase in yield (output per hectare). We explain why Russian grain yields have been rising. The chapter also examines the outlook for Russian grain production and exports.

The chapter is structured as follows. The next section discusses Russia's importance in world grain markets, followed by an analysis of the close connection between the Russian grain and livestock sectors. The following section examines why Russian grain production has increased substantially since 2000. The effect on grain production and trade of state policy and changes in the value of the Russian ruble (especially its exchange rate vis-à-vis the U.S. dollar) is also assessed. The last section presents the outlook for the Russian grain economy, in particular the volumes of production and exports. A model of world agriculture and trade developed by the Economic Research Service (ERS) within the United States Department of Agriculture (USDA) is used to project future Russian grain area, yield, production, and exports to the year 2029.

\section{Russia in the World Grain Market}

During 2016-2019, Russia supplied 10-14 percent of total world grain exports, and about 20 percent of wheat exports (see Fig. 1). In recent years the country has supplanted the United States as the world's top wheat exporter. The country is also a major exporter of barley, with 17 percent world export share in 2016-2019, while Russia's corn export share during that time was 2.7 percent. $^{1}$

During 2016-2019, Russia's total grain exports averaged $44 \mathrm{mmt}$ a year, and exports of wheat $35 \mathrm{mmt}$. In volume terms, wheat accounted for 79 percent of Russia's total grain exports, while barley and corn both had shares of 10 percent during the same period. Russia currently imports almost no grain. 


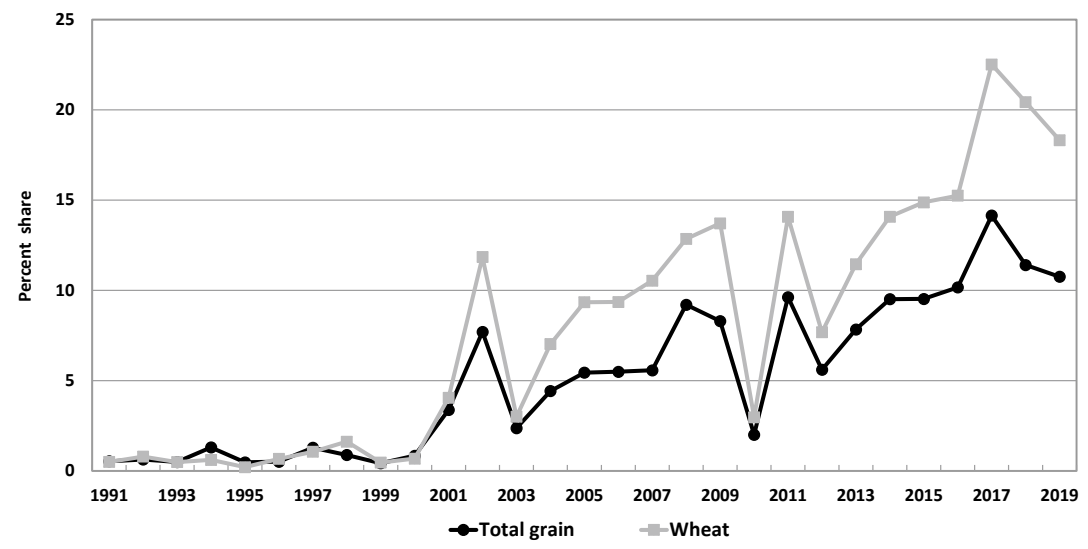

Fig. 1 Russia's share in world grain exports (Source USDA Production, Supply, and Distribution Online, accessed 27 July 2020 Note Exports are gross)

Currently, the main foreign markets for Russian grain are the Middle East and North Africa (especially Turkey, Egypt, Sudan, Morocco, and Yemen), certain Asian countries (such as Bangladesh and Vietnam), Nigeria, and some countries formerly within the USSR (such as Latvia and Azerbaijan). Most of the wheat exported is of low milling quality used to produce (human) food products, though it can also be used as animal feed.

\section{RuSSIA's GRAIN ECONOMY AND THE LIVESTOCK SECTOR}

Historically, Russia's grain economy has been closely linked to its livestock sector. During the last two decades of the Soviet Union, the main goal of state agricultural policy was to expand the production and consumption of meat and other animal products in order to raise the country's standard of living. Between 1970 and 1990, a policy built on large subsidies to both producers and consumers succeeded in increasing meat production by more than 50 percent. ${ }^{2}$ To help supply its livestock sector with animal feed, the Soviet Union became a larger importer of grain, soybeans, and soybean meal, to the benefit of large producers of these bulk crops such as the United States, Canada, and Australia. 
The transition from a planned to a market economy in the 1990s led to contraction in the livestock sector. Because of severe financial constraints, the large budget subsidies to agriculture-and especially the previously favoured livestock sector-were mostly terminated. Price reform also ended the indirect subsidies that agriculture had enjoyed during the Soviet period, whereby output prices were set high relative to input prices. ${ }^{3}$ Consequently, during the 1990s the terms of trade for Russian agricultural producers (the ratio of output to input prices) fell by about 75 percent. Substantially higher prices for inputs resulted in a large decline in their use, which contributed to the extreme drop in agricultural production, both in ruble value and in volume.

During the 1990s, product output in Russia fell by about a half. ${ }^{4}$ As livestock herds declined in size, the demand for animal feed dropped sharply. Russia's large imports of feed grain (as well as soybeans and soybean meal) largely ended, and grain production declined by about a third, from an annual average of $95 \mathrm{mmt}$ during 1987-1991 to $63 \mathrm{mmt}$ during 1996-2000 (see Table 1). Rather than importing a lot of animal feed to maintain a large and costly livestock sector, Russia increased its imports of meat, from an annual average of $1.9 \mathrm{mmt}$ during 1989-1991 to $3.1 \mathrm{mmt}$ during $2006-2010 .^{5}$

The extreme downsizing of agriculture during the 1990s caused severe hardship for producers and was regarded by the Russian government as a disaster. However, the major restructuring of agricultural production and trade during the decade appears to have been an economically rational and necessary correction to the overexpansion of the sector during the last decades of the Soviet period, especially of livestock.

\section{Growth in Grain Production}

After 2000, Russian grain production began to slowly rise, and then increased more rapidly after 2008. From 1996-2000 to 2016-2019, annual average Russian grain output increased from 63 to $115 \mathrm{mmt}$ (see Table 1). The growth from 2011-2015 to 2016-2019 was especially high, with annual average production over the two periods rising by almost a third. In addition, from 1996-2000 to 2016-2019, the annual production of wheat more than doubled, from 34 to $76 \mathrm{mmt}$ (all output figures are annual averages). Corn output also rose at a fast rate to $13.5 \mathrm{mmt}$ by 2016-2019 (though from a low base). However, the annual production of other coarse grains, including barley, rye, and 
Table 1 Russian Grain Production and Trade

\begin{tabular}{|c|c|c|c|c|c|c|c|}
\hline & $\begin{array}{c}1987- \\
1991\end{array}$ & $\begin{array}{c}1992- \\
1995\end{array}$ & $\begin{array}{c}1996- \\
2000\end{array}$ & $\begin{array}{l}2001- \\
2005\end{array}$ & $\begin{array}{c}2006- \\
2010\end{array}$ & $\begin{array}{l}2011- \\
2015\end{array}$ & $2016-2019$ \\
\hline Production & \multicolumn{7}{|c|}{ Million tons } \\
\hline wheat & 41.8 & 38.0 & 34.3 & 44.9 & 52.3 & 53.2 & 75.7 \\
\hline barley & 23.4 & 24.2 & 14.2 & 17.8 & 16.6 & 16.7 & 18.6 \\
\hline corn & 3.3 & 1.8 & 1.4 & 2.2 & 4.2 & 10.3 & 13.5 \\
\hline $\begin{array}{l}\text { other } \\
\text { grain }\end{array}$ & 26.2 & 19.7 & 12.8 & 11.2 & 8.8 & 8.1 & 7.3 \\
\hline $\begin{array}{l}\text { total } \\
\text { grain }\end{array}$ & 94.8 & 83.7 & 62.7 & 76.1 & 81.9 & 88.3 & 115.2 \\
\hline $\begin{array}{l}\text { Area } \\
\text { (barvested) }\end{array}$ & \multicolumn{7}{|c|}{ Million hectares } \\
\hline wheat & 23.8 & 22.5 & 21.5 & 22.9 & 24.2 & 23.7 & 27.0 \\
\hline barley & 15.0 & 14.3 & 9.1 & 9.3 & 8.0 & 8.0 & 8.0 \\
\hline corn & 1.1 & 0.6 & 0.6 & 0.7 & 1.2 & 2.2 & 2.6 \\
\hline $\begin{array}{l}\text { other } \\
\text { grain }\end{array}$ & 18.3 & 13.6 & 9.2 & 6.9 & 5.3 & 4.9 & 4.0 \\
\hline $\begin{array}{l}\text { total } \\
\text { grain }\end{array}$ & 58.2 & 51.1 & 40.4 & 39.8 & 38.8 & 38.9 & 41.6 \\
\hline rield & \multicolumn{7}{|c|}{ Tons per hectare } \\
\hline wheat & 1.76 & 1.69 & 1.59 & 1.96 & 2.16 & 2.24 & 2.80 \\
\hline barley & 1.56 & 1.69 & 1.57 & 1.91 & 2.08 & 2.07 & 2.34 \\
\hline corn & 3.00 & 2.82 & 2.34 & 3.30 & 3.42 & 4.61 & 5.24 \\
\hline $\begin{array}{l}\text { other } \\
\text { grain }\end{array}$ & 1.43 & 1.45 & 1.39 & 1.62 & 1.66 & 1.64 & 1.83 \\
\hline $\begin{array}{l}\text { total } \\
\text { grain }\end{array}$ & 1.63 & 1.64 & 1.55 & 1.91 & 2.11 & 2.27 & 2.77 \\
\hline $\begin{array}{l}\text { Exports } \\
\text { (gross) }\end{array}$ & \multicolumn{7}{|c|}{ Million tons } \\
\hline wheat & 0.9 & 0.6 & 0.9 & 7.7 & 12.8 & 20.0 & 34.9 \\
\hline barley & 0.1 & 0.8 & 0.5 & 2.2 & 1.8 & 3.6 & 4.4 \\
\hline corn & 0.3 & 0.0 & 0.0 & 0.0 & 0.4 & 3.2 & 4.5 \\
\hline $\begin{array}{l}\text { other } \\
\text { grain }\end{array}$ & 0.3 & 0.3 & 0.0 & 0.1 & 0.0 & 0.1 & 0.2 \\
\hline $\begin{array}{l}\text { total } \\
\text { grain }\end{array}$ & 1.6 & 1.6 & 1.4 & 10.0 & 15.0 & 26.9 & 44.0 \\
\hline & \multicolumn{7}{|c|}{ Million tons } \\
\hline $\begin{array}{l}\text { Net } \\
\text { trade }\end{array}$ & -21.1 & -7.7 & -2.6 & 8.3 & 14.3 & 25.9 & 43.4 \\
\hline
\end{tabular}

Note Grain excludes rice, buckwheat, and pulses. Figures are annual average over the period identified. Net trade is for total grain; positive values are net exports, negative values net imports Source USDA Production, Supply, and Distribution Online, and for yield, computed from data from that source 
oats, fell collectively from 1987-1991 to 1996-2000 by over half, and to 2016-2019 by a further 43 percent (see Table 1 ).

Contraction of the livestock sector during the 1990s contributed to the growth in grain exports after 2000 by reducing demand for domestic feed, thereby freeing up output for sale abroad. The downsizing of the livestock sector, replacing of domestically produced livestock products with imports, and rising grain exports after 2000 are consistent with the country's fundamental cost competitiveness (or comparative advantage) in world markets. ${ }^{6}$

Russia's move from being a large grain importer during the late Soviet period to a major exporter has resulted in about $70 \mathrm{mmt}$ of more grain being available on the world market (see Fig. 2). Similar to Russia, both Ukraine and Kazakhstan have experienced a similar restructuring of their grain and livestock economies during their transition from planned to

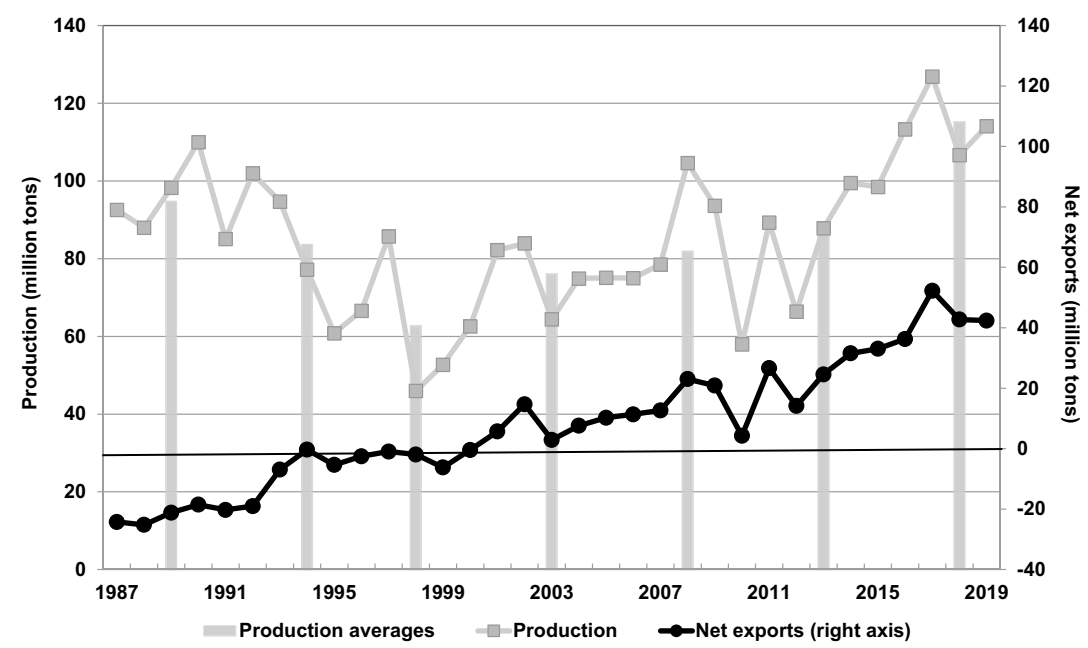

Fig. 2 Russian grain production and net trade (Source Russian Federal Service of State Statistics, Russian Statistical Yearbook, various issues, accessed 31 July 2020; USDA Production, Supply, and Distribution Online, accessed 27 July 2020. Note The bars give average annual grain production over the periods 1987-1991, 1992-1995, 1996-2000, 2001-2005, 2006-2010, 2011-2015, and 2016-2019. Negative net grain exports are net imports) 
market economies. If one includes those two countries with Russia, an additional $120 \mathrm{mmt}$ of grain is available on the world market.

\subsection{Grain Area}

Given that grain output can be expressed as grain area times yield, one way of examining why Russian grain production began to rise around 2000 is to focus on these two elements. Russian grain output has been increasing mainly because of growth in yields rather than area. Total Russian grain area (harvested) dropped from 1987-1991 to 1996-2000 by 30 percent, and since that time has remained fairly flat, with an annual average of 42 million hectares during 2016-2019. The main reason Russian grain area has not rebounded from its drop during the 1990s appears to be that much of the abandoned land was in remote regions with high production costs, mainly in the northern and eastern parts of the country, though also in some arid regions in southern European Russia. $^{7}$

However, some switch in area has occurred between the various grain crops, with the changes in area mirroring those in production. From 1987-1991 to 2016-19, the area devoted to wheat increased from 24 to 27 million hectares, while over the same period the area cultivated with corn more than doubled (though from a small base) to 2.6 million hectares. On other hand, area for the other coarse grains (such as barley, rye, and oats) decreased over this period by almost 80 percent (see Table $1)$.

\subsection{Grain Yield}

In contrast to area, Russian grain yields since 2000 have increased substantially. From 1996-2000 to 2016-2019, total grain yield rose from 1.55 tonnes per hectare (annual average) to 2.77 tonnes per hectare (see Table 1). One reason for the growth was a rebound in fertiliser use, which during the 1990s had declined by around 80 percent (as measured by kilograms of fertiliser used per hectare of sown grain area), as part of the overall decline in agricultural input use discussed earlier. From 2000 to 2018 , fertiliser use per hectare of Russian grain tripled, from 20 to $60 \mathrm{~kg}$ per sown hectare. ${ }^{8}$

Yields can grow from increasing the amount of inputs (such as fertiliser) used in production, or by raising the productivity of those inputs 
(measured by units of output per units of input used in production). One way to raise productivity is through technological change. Russian agriculture, including the grain sector, has benefited from such improvement, partly from the use of new and superior inputs (called embodied technological progress). For the grain sector, this has taken the form of new high-quality seed varieties (such as high-yielding hybrid corn seed) and modern machinery, much of it imported. Modern techniques such as soil testing for fertiliser rates have also been adopted. Productivity-enhancing investment and technological change are occurring in Russian agriculture. ${ }^{9}$ For example, between 2010 and 2015, investment in machinery and equipment grew by 120 percent in real terms.

Another reason why the Russian agricultural sector in general, and grain yields in particular, improved was that the new market-oriented economy freed farms from the dictates of central planning. Producers, rather than distant planners, could now determine for themselves the mix of goods to produce and the inputs to use in production. Economists call the specific type of gain that can ensue from such changes improvement in allocative efficiency, which can have two components.

The first is a gain in the allocative efficiency in production, whereby producers/farms determine the optimal mix of inputs to use in making a given volume of output. ${ }^{10}$ The second is a gain in the allocative efficiency in consumption, whereby in determining the mix and volume of goods to make, producers respond to market demand rather than planners' orders. The market-generated changes in the composition of output raise consumer welfare, and thereby the welfare of the overall economy. ${ }^{\text {1l }}$

Improvement in allocative efficiency can be difficult to measure. However, the major changes in the mix of specific grain products in total grain area and production since 2000 (more wheat and corn and less other coarse grains) are indicators of likely improvement in allocative efficiency.

An example of an allocative efficiency gain in production within the grain economy that is amenable to some measurement is that since 2000, area has been moving from spring wheat to higher-yielding winter wheat. Between 2000-2002 and 2017-2019, Russian spring wheat area fell from an annual average of 14.2 to 11.6 million hectares, while Russian winter wheat area rose from 8.7 to 15.3 million hectares. ${ }^{12}$ Winter wheat is a higher-yielding crop than spring wheat, and after 2000 investment in its production pushed its trend yield up, while spring wheat yields grew only slightly. Figure 3 shows that since 2000, Russian winter wheat yields have 


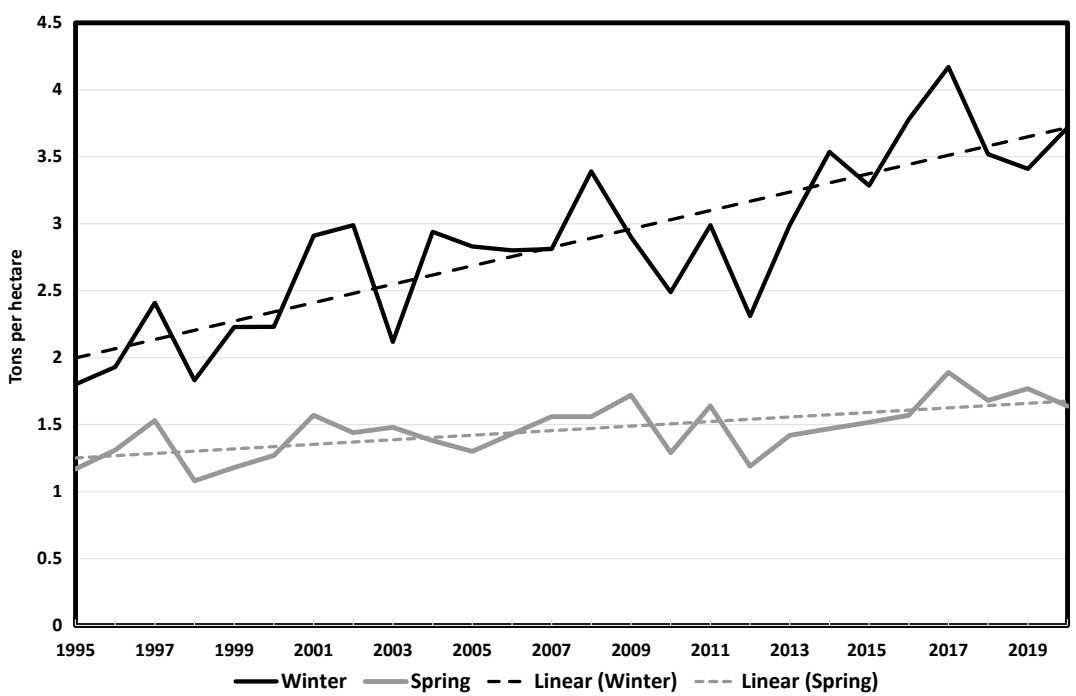

Fig. 3 Russian Winter Versus Spring Wheat Yield (Source Calculated from USDA Production, Supply, and Distribution Online, accessed 27 July 2020)

risen at more than twice the rate of spring wheat yields, increasing the yield gap between the two crops. The switch from spring to winter wheat is raising the allocative efficiency of grain production, and thereby overall grain yields and output, by moving resources (in particular land) from producing a less productive type of wheat to a more productive one.

An appeal of allocative efficiency gains that can increase input productivity and output, as well as consumer welfare, is that the benefits achieved do not require technological change. Russia's allocative efficiency gains have been generated by systemic change, whereby marketoriented producers replaced planners in determining the mix of goods produced and the inputs used in their production. ${ }^{13}$

That said, technological change and improvement in allocative efficiency can both increase the productivity of inputs used in production, thereby raising the volume of output produced by a given amount of inputs. Empirical studies find that since 2000 productivity in Russian agriculture has been increasing. From 1999 to 2008, total factor productivity (TFP) in Russian agriculture grew by about a quarter. ${ }^{14}$ Other analysts concluded that during 2000-2007, TFP rose even more substantially, by 
54 percent. ${ }^{15}$ Still others found that from 1998 to 2013 , agricultural TFP increased by 72 percent. ${ }^{16}$ Productivity growth was highest in southern European Russia, which specialises in grain and oilseeds.

\section{Producers}

The systemic change of moving from a planned to a market economy allowed agricultural producers to improve allocative efficiency by switching to a more productive mix of inputs and a more consumer-satisfying mix of outputs. Around 2000, another major systemic/institutional change occurred in Russian agriculture whereby a new type of agricultural operator emerged which took advantage of the opportunities offered by the market economy to increase productivity and profit. Before discussing these new operators, we will review the main types of producers in Russian agriculture.

During the 2000s, several types of agricultural producers developed, but in 2000 there were three major types in Russia: (1) the former state and collective farms inherited from the Soviet period; (2) household plots; and (3) new private family farms. ${ }^{17}$ The dominant producer has been the former Soviet state and collective farms, which in the 1990s were forced officially to reorganise. Most became corporate, and in particular 'joint stock' enterprises that issued ownership vouchers to their managers and workers, giving them a share in the farm's land and other assets. Individuals could use these vouchers to obtain land and leave the farm to work as private farmers, or they could sell their vouchers to the farm management and remain on the farm as hired labour. Most workers chose the latter option. These farms retained their large size from the Soviet period, typically holding thousands of hectares.

A second type of producer is household plots, also inherited from the Soviet period, where households on the large farms were given small plots to tend (typically only half a hectare). Households tended to produce animal husbandry products, fruit, vegetables (including potatoes), and honey; they contributed less than 1 percent of grain supply. Production from household plots could be consumed by the households themselves or sold in farmers' private markets. ${ }^{18}$

The third type of producer is private family (also called 'peasant') farms. These were created mainly by workers on the new corporate farms using their ownership vouchers to obtain land and break away as independent producers. These farms specialise in producing bulk crops such 
as grain and oilseeds, and by 2018 they held about held 34 percent of Russian grain area. In that year, they accounted for 29 percent of Russian grain output, a sizeable increase from their share in 2000 of 8 percent. ${ }^{19}$

In the early years of the 2000s, a new type of agricultural producer emerged call 'new operators', agroholdings, which are vertically integrated enterprises that typically combine primary agriculture, processing, distribution, and retail sale. ${ }^{20}$ Agroholdings usually acquire a number of existing corporate farms and try to improve them, by cutting waste and reducing production costs, and generally becoming more profit-oriented. Agroholding management typically comes from outside of agriculture, and brings investment, management skills, and technological innovation into the sector (including foreign technology and know-how).

The Russian Federal Service of State Statistics (Rosstat) does not collect separate data about agroholdings. Some authors argue that agroholdings hinder grain production and exports due to management and financial problems, but those conclusions have been shown to be erroneous. ${ }^{21}$ However, an emerging literature has revealed other trends that are important to Russia's status as a major grain producer and exporter. The largest agroholdings are several hundred thousand hectares in size, which means that they are many times the size of Soviet-era state and collective farms. $^{22}$ Uzun calculated that in 2016 agroholdings held 11 percent of Russia's total arable land and produced 23 percent of the country's grain. ${ }^{23}$ Agroholdings are particularly prominent in the Russian grain belt of south-central and southern European Russia, which covers the country's rich black soil region. ${ }^{24}$

Some specialists argue that the new operators, and especially agroholdings, outperform other agricultural producers in terms of productivity, and therefore are a major source of the growth in Russian agricultural production (including grain) since 2000. ${ }^{25}$ Uzun and Shagaida show that agroholdings accounted for about 54 percent of all production, 56 percent of gross earnings, and more than 41 percent of total employment among Russia's agricultural enterprises in 2016. ${ }^{26}$ Some analysts argue that the agroholdings benefit not from economies of scale but economies of scope, given the continued institutional dysfunctionalities of Russian agriculture. ${ }^{27}$ Other analysts find that agroholdings are neither more productive nor profitable than other large Russian agricultural enterprises. ${ }^{28}$ Perhaps the agroholdings have become so large and unwieldy that they suffer from diseconomies of scale. The data from Uzun and Shagaida, however, cast doubt on these latter lines of argumentation. 
To summarise, the causality chain in growing Russian grain exports since 2000 is as follows: systemic change combined with improved farm management motivated both technological progress and gains in allocative efficiency. The resulting increase in input productivity raised grain yields, thereby generating surplus production above domestic needs available for export.

\section{State Agricultural and Grain Policy}

Russian agricultural policy played mixed role in the post-2000 success of the grain economy. In some ways, agrarian policy facilitated grain production, for example by providing debt relief to large farms that freed up money for investment and increasing production; by establishing a price floor and a state contract system so that in years of good harvests farms would have an outlet for sales at a guaranteed price; by providing access to subsidised seed, fertiliser, fuel, and rail transport. Further, in 2005 the federal government identified agriculture as a national priority area (along with health, education, and housing) that would receive increased funding. From 2005 to 2010 , total state support to agriculture rose by 135 percent in real (inflation-adjusted) terms. In other ways, the government impeded rather than promoted grain exports. In the 2000s, the Russian government took strong action to reverse the extreme decline of the livestock sector during the 1990s. As during the Soviet period, state budget subsidies favoured the livestock sector. In 2003, the government also introduced tariff-rate quotas on pork, poultry, and beef, which remained in effect into 2020 except for pork imports. The government also imposed health and sanitary restrictions on imports of meat, a policy that continued after Russia joined the World Trade Organization in 2012.

Russian agricultural and trade policy has promoted the interests of the livestock sector over that of grain. From 1996-2000 to 2016-2019, Russian meat production increased on annual average by 150 percent, from 3.6 to $9.0 \mathrm{mmt}^{29}$ However, by increasing domestic demand for feed, the growth of the livestock sector has the isolated effect of reducing grain exports. Furthermore, when domestic grain supplies have been low, say because of drought or other bad weather, or when grain prices have been high, the Russian government has used an array of policies to restrict grain exports. The controls are intended to help domestic food consumers and the feed-using livestock sector by keeping more grain within the country and lowering grain (and thereby food-related 
and animal feed) prices. These restrictions have included export taxes, a complete export ban that lasted from August 2010 to July 2011, and taxing and obstructing the transport of grain to exporting ports. ${ }^{30}$ In early 2020, Russia imposed a quota on grain exports, this time in response to concerns that the COVID-19 outbreak could disrupt the internal grain market and cause food price inflation. Combined with Russia's climate and volatile weather that can generate poor grain harvests (mainly because of drought but sometimes also because of excessive rainfall during planting or harvesting), such policies lower the country's reliability as a grain exporter. ${ }^{31}$

\subsection{Ruble Exchange Rate and Grain Exports}

A development that helped Russian grain production and exports in the years immediately following the country's macroeconomic crisis of 1997-1998 was the extreme crisis-generated depreciation of the ruble vis-à-vis the U.S. dollar and other major currencies. ${ }^{32}$ During 19971999, the ruble depreciated against the dollar in real (inflation-adjusted) terms by 47 percent, which greatly increased the price competitiveness of Russian grain exports on the world market. ${ }^{33}$ Currency depreciation also raised the prices received by domestic producers of traded goods, thereby motivating more production.

However, once the Russian economy stabilised after the 1997-1998 crisis and GDP growth resumed, the ruble began steadily to appreciate in real terms against the U.S. dollar and other major currencies. From 2000 to 2009 , the ruble appreciated in real terms against the dollar by about 150 percent. This real appreciation occurred because renewed growth coincided with domestic price inflation, while the nominal exchange rate remained fairly stable. Inflation in excess of nominal currency depreciation appreciates a country's currency in real terms, thereby making its exports less price competitive on the world market. More intuitively, inflation hurts a country's export price competitiveness and world market share of exported products by raising the prices of its exports to foreign purchasers, and the stable nominal exchange rate does not correct that loss in price competitiveness.

Since the economic crisis of 1997-1998, Russia has experienced a cycle of economic crises that substantially depreciate the currency in real terms, followed by a period of macro stability and growth that appreciate the ruble in real terms against the U.S. dollar). The world financial/economic 
crisis of 2008-2009 hit the Russian economy and the ruble depreciated against the dollar in 2009 by 12 percent. During 2010-2013, the ruble appreciated in real terms by 19 percent. The economic crisis of 20142015 , caused in part by geopolitical tensions with the West and Western economic sanctions (stemming from Russia's occupation of the Crimea and eastern parts of Ukraine), generated depreciation of the ruble in 2014-2016 of about 40 percent. That was followed again by ruble appreciation over 2017-2019 of 15 percent. In 2020, the COVID-19 outbreak plunged the Russian economy once again into crisis, with the ruble depreciating against the dollar from mid-January to the beginning of August 2020 by about 18 percent. ${ }^{34}$ These macroeconomic-generated jolts to the ruble exchange rate have in turn jolted the country's foreign trade, including grain exports.

\section{OUTLOOK}

Continued growth in Russian grain exports will require further increases in grain production. Our crystal ball-gazing involves examining the prospects for grain area and yields. For grain area, the question concerns the likelihood of returning to production the grain area removed from grain sowing since the Soviet period. The Ministry of Agriculture has stated its intent to bring back into production as much as 12 million hectares of unused and abandoned farm land by 2024, requiring federal expenditures of hundreds of billions of rubles. ${ }^{35}$ According to one study, only 5.3 million hectares of the remaining idled land for all agriculture (not just grain) qualifies for being returned to the plow, if soil and climatic conditions, accessibility, and environmental trade-offs are all considered. ${ }^{36}$ Much of Russia's abandoned area is in remote regions in the northern and eastern parts of the country, though also in some arid regions in southern European Russia. ${ }^{37}$ Returning the land to the plow requires that world grain prices rise substantially and remain high, to cover both the fixed costs of making the land suitable again for cultivation, and the high variable costs of production.

Studies of the effect of climate change on Russian agriculture argue that rising global temperature could make currently unused land in northern parts of Russia amenable to agricultural use. ${ }^{38}$ However, whether or not grain production on the new land would be commercially viable is unclear, given the relative isolation and marginal conditions of production. Another consideration is that some of the grain area lost 
during the past decades was not abandoned, but rather switched in use from producing grain to sunflower seed, Russia's main oilseed crop. This occurred largely in Russia's major grain and oilseed producing districts in southern and central European Russia. ${ }^{39}$

Russia has made tremendous progress in increasing grain yields since 2000 , both in an absolute sense, and in closing the yield gap with major Western producers that also have large endowments of agricultural land, such as the United States and Canada. During 1996-2000, Russian wheat yields (annual average) were 58 percent and 67 percent of the levels in the United States and Canada, respectively. However, by 2016-2019, Russia had closed the yield gap to 84 percent and 83 percent $(2.80$ tonnes per hectare in Russia, 3.34 in the United States, and 3.39 in Canada. ${ }^{40}$ The fact that Russia is narrowing the yield gap with major Western producers, while reaching its limit of switching from spring to higher-yielding winter wheat, suggests that Russian grain yields will continue to grow, though not at the high rate of the 2010 s.

Given that Russian agriculture continues to suffer from major problems, the potential exists to raise grain yields further and improve the overall performance of the agricultural economy by correcting (or mitigating) these weaknesses. We mentioned earlier in discussing agroholdings that Russian agriculture continues to endure deficient commercial services and institutional infrastructure to support the sector. A major study on Russian agriculture conducted two decades ago identified those weaknesses as the major problem within the Russian agro-food system. ${ }^{41}$ Although progress has certainly been made in the last couple of decades in strengthening the Russian agricultural economy, deficiencies remain (as they do in the agricultural sector of most developed states, so Russia is hardly unique).

Another continued weakness in Russian agricultural operations is the shortage of skilled farm labor, in such jobs as machine operators, technical and production specialists, management, marketing personnel, and financial. ${ }^{42}$ The educational and research establishment also remains subpar, suffering from conservatism and institutional rigidity. ${ }^{43}$

Climate change could also affect future Russian grain yields. In the main grain-producing regions of southern and central European Russia, higher temperatures and other climatic changes are predicted to create greater aridity, threaten water supplies, and increase droughts. Climate change is likely to cause grain yields initially to fall. ${ }^{44}$ However, if producers adapt to the new conditions, such as by improving irrigation 
and changing the sowing schedule, grain yields could then rise. On the other hand, although climate change could improve the productivity of grain production in Russia's north and Siberia, it will hurt grain productivity in the main producing regions in the south, with an aggregate net effect for the grain economy. ${ }^{45}$

A model for world agriculture and trade created by the United States Department of Agriculture's Economic Research Service annually makes projections of the volumes of world production and trade for major agricultural commodities out to ten years. The United States Department of Agriculture (USDA) projects that over the next decade world grain prices will fall rather than rise. ${ }^{46}$

We next examine the projections generated by this model for Russian grain production and trade, plus area and yield, to 2029.47 The model employed is the Country-Commodity Linked (CCL) System, that covers 44 countries and regions, and generates annual volumes of production, consumption/use, and trade, as well as prices, for 24 agricultural commodities. The model is dynamic and partial equilibrium in nature, and consists of supply and demand equations for products that use synthetic (rather than estimated) own and cross-price elasticities. In the following discussion, projected growth to 2029 volumes and levels is relative to the annual average for 2016-2019.

The model projects that by 2029 , the average area devoted to grain will grow by only half a percent from 41.6 to 41.8 million hectares (see Table 2). Russia's wheat area is projected to grow by 17 percent to about 28 million hectares.

The projections in Table 2 indicate that although Russian grain production and exports will likely continue to rise in the 2020s, the growth will occur at a slower rate than during the 2010s, again with almost all the increase driven by rising yields. Although production and exports will continue to increase, the rate of high growth in providing grain to the world could be winding down.

According to the USDA model, Russian grain yields are projected to increase to 2029 to almost 3 tonnes per hectare. Wheat yield growth of 7.7 percent will be just slightly below that for total grain of 8 percent. These results are also consistent with our previous discussion that Russian grain yields should continue to grow, but at a lower rate than during 2016-2019.

The projections show that the growth in Russian grain production will be driven almost wholly by rising yields, such that total grain output is 
Table 2 USDA Projections for Russia's Grain Economy

\begin{tabular}{|c|c|c|c|}
\hline & $2016-19$ & 2029 projection & Growth (\%) \\
\hline Production & & Million tons & \\
\hline wheat & 75.7 & 83.5 & 10.3 \\
\hline barley & 18.6 & 21.4 & 15.1 \\
\hline corn & 13.5 & 14.0 & 3.7 \\
\hline total grain & 115.2 & 125.1 & 8.6 \\
\hline Area (barvested) & & Million hectares & \\
\hline wheat & 23.7 & 27.7 & 16.9 \\
\hline barley & 8.0 & 8.1 & 1.3 \\
\hline corn & 2.6 & 2.6 & 0.0 \\
\hline total grain & 41.6 & 41.8 & 0.5 \\
\hline rield & & Tons per hectare & \\
\hline wheat & 2.80 & 3.01 & 7.7 \\
\hline barley & 2.34 & 2.64 & 12.9 \\
\hline corn & 5.24 & 5.38 & 2.8 \\
\hline total grain & 2.77 & 2.99 & 8.0 \\
\hline Exports (gross) & & Million tons & \\
\hline wheat & 34.9 & 38.8 & 11.2 \\
\hline barley & 4.4 & 7.3 & 65.9 \\
\hline corn & 4.5 & 4.9 & 8.9 \\
\hline total grain & 44.0 & 51.3 & 16.6 \\
\hline Meat production & & Million tons & \\
\hline beef & 1.35 & 1.23 & -8.9 \\
\hline pork & 3.06 & 3.53 & 15.4 \\
\hline poultry & 4.59 & 5.26 & 14.6 \\
\hline total meat & 9.00 & 10.02 & 11.3 \\
\hline Grain used as feed & & Million tons & \\
\hline wheat & 18.0 & 23.1 & 28.3 \\
\hline barley & 9.6 & 10.1 & 5.2 \\
\hline corn & 8.1 & 8.2 & 1.2 \\
\hline total grain & 39.3 & 44.9 & 14.2 \\
\hline
\end{tabular}

Note Total grain excludes rice, buckwheat, and pulses, and total meat includes beef, pork, and poultry. Data for 2016-2019 are annual average over the period Source Same as Table 1

projected to expand to 2029 by 8.6 percent. Production is projected to increase from an annual average of $115 \mathrm{mmt}$ during 2016-2019 to 125 $\mathrm{mmt}$ in 2029. Wheat output is projected to rise across the two periods from 76 to $83 \mathrm{mmt}$.

Growth in the livestock sector cuts into surplus grain production for export by increasing domestic demand for animal feed. The model 
projects that meat production (beef, pork, and chicken) will grow to 2029 by 11 percent to $10 \mathrm{mmt}$. Correspondingly, the total amount of grain used as domestic animal feed will rise to 2029 by 14 percent to $45 \mathrm{mmt}$, and wheat feed use will rise by 28 percent to $23 \mathrm{mmt}$. The increase in the amount of total grain and wheat used as feed will be 5.6 and $5.1 \mathrm{mmt}$, respectively.

The model projects that total grain exports will rise between 20162019 (annual average) and 2029 from 44 to $51 \mathrm{mmt}$, and wheat exports from 35 to $39 \mathrm{mmt}$. Barley exports will increase by two-thirds, although from a much smaller base.

After the surges in world agricultural prices over 2006-2012, some observers argued that the three main grain-producing countries of the former Soviet Union-Russia, Ukraine, and Kazakhstan-had the potential to raise their grain production substantially, by increasing both area and yields (depending on the specific country). The additional grain output would raise world supplies considerably, thereby working to lower grain prices and bolster world food security. Returning abandoned agricultural land in Russia to grain production would help make this three-country region a breadbasket to the world. ${ }^{48}$

\section{Notes}

1. See U.S. Department of Agriculture, Foreign Agricultural Service, 'Production, Supply and Distribution Online', n.d. https://apps.fas.usda. gov/psdonline/app/index.html\#/app/home; and William M. Liefert and Olga Liefert, 'Russian Agricultural Trade and World Markets', Russian Journal of Economics 6, no. 1 (2020): 56-70.

2. William Liefert and Johan Swinnen, 'Changes in Agricultural Markets in Transition Economies', Agricultural Economic Report no. 806 (Washington, DC: Economic Research Service, USDA, 2002).

3. William M. Liefert and Olga Liefert, 'Russian Agriculture During Transition: Performance, Global Impact, and Outlook', Applied Economic Perspectives and Policy 34, no. I (2012): 37-75.

4. Ibid.

5. United States Department of Agriculture, Foreign Agriculture Service, 'Production, Supply and Demand Online Database'.

6. William M. Liefert, 'Comparative (Dis?) Advantage in Russian Agriculture', American Journal of Agricultural Economics 84, no. 3 (2002): 762-767.

7. Vasilii Uzun, Valery Saraikin, Ekaterina Gataulina, Natalya Shagaida, Renata Yanbykh, Sebastien Mary, and Sergio Gomez y Paloma, 'Prospects 
of the Farming Sector and Rural Development in View of Food Security: The Case of the Russian Federation', (Luxembourg: European Commission, 2014); and William M. Liefert and Olga Liefert, 'Russia's Potential to Increase Grain Production by Expanding Area', Eurasian Geography and Economics 56, no. 5 (2015): 505-523.

8. Rosstat, Rossiiskii statisticheskii ezhegodnik (Moscow: Rosstat, various years).

9. L. I. Gokhberg, I. Kuzminov, A. Chulok, and T. Thurner, 'The Future of Russia's Agriculture and Food Industry Between Global Opportunities and Technological Restrictions', International Journal of Agricultural Sustainability 15, no. 4 (2017): 457-466; and Ilya Kuzminov, Leonid Gokhberg, Thomas Thurner, and Elena Khabirova, 'The Current State of the Russian Agricultural Sector', EuroChoices 17, no. l (2018): 52-57.

10. An example of improvement in the allocative efficiency of production is if two producers are using the same two inputs in production, but one is using too much of one input, and the other too much of the other, given the inputs' marginal productivity. If the two producers exchange among themselves some of their overused input for their underused one, both could increase their volume of output.

11. Although the focus of this discussion is on improvement in the allocative efficiency of grain production and yields, the major changes in the structure of Russian agricultural production since 2000 suggest that huge gains have been made in the allocative efficiency of consumption/use throughout the Russian agricultural economy. Poultry/chicken was a neglected livestock product during the Soviet planned period. However, between 2000 and 2019 production has skyrocketed, rising by over 450 percent from 0.81 to $4.67 \mathrm{mmt}$, as the market responded to strong demand for this relatively inexpensive meat (compared to beef and pork). The production of oilseeds was also neglected during the Soviet period. From 1996-2000 to 2016-2019, output of Russia's main oilseed, sunflowerseed, increased by an average of 275 percent to $12.3 \mathrm{mmt}$ a year. Russia has also started to expand the production of soybeans, with output averaging $3.8 \mathrm{mmt}$ during 2016-2019. All data from United States Department of Agriculture, Foreign Agriculture Service, 'Production, Supply and Demand Online Database'.

12. United States Department of Agriculture, Foreign Agriculture Service, 'Production, Supply and Demand Online Database'.

13. Trade based on comparative advantage is related to allocative efficiency, in that it is an extension of allocative efficiency decision-making involving production and market exchange to include foreign trade.

14. Raushan Bokusheva, Heinrich Hockmann, and Subal C. Kumbhakar, 'Dynamics of Productivity and Technical Efficiency in Russian Agriculture', European Review of Agricultural Economics 39, no. 4 (2011): 
611-37. Total factor productivity for a sector such as agriculture is computed by dividing total agricultural output by the weighted average of all inputs used in production.

15. Johan F. M. Swinnen, Kristine Van Herck and Liesbet Vranken, 'Agricultural Productivity Paths in Central and Eastern European Countries and the Former Soviet Union: The Role of Reforms, Initial Conditions and Induced Technological Change', in Productivity Growth in Agriculture: An International Perspective, eds. Keith O. Fuglie, Sun Ling Wang, and V. Eldon Ball (Oxfordshire, UK: CABI International, 2012), 127-44.

16. Nicholas Rada, William M. Liefert, and Olga Liefert, 'Productivity Growth and the Revival of Russian Agriculture', Economic Research Report no. 228 (Washington, DC: Economic Research Service, USDA, 2017).

17. See Natalya Shagaida and Zvi Lerman, 'Land Reform and Development of Land Markets', in Russia's Agriculture in Transition: Factor Markets and Constraints on Growth, ed. Zvi Lerman (Lanham, MD: Lexington Books, 2008), 137-183; and Stephen K. Wegren, 'Land Reform in Russia: What Went Wrong?’ Post-Soviet Affairs 24, no. 2 (2008): 121-147.

18. Although using a small share of total farmland during both the Soviet and post-Soviet periods, household plots have produced a disproportionate share of the total ruble value of Russian agricultural output-around 50 percent in 2000 , though by 2020 the value was less than 30 percent. Historically, plots produce mostly high value goods such as meat, dairy, vegetables, and fruit, although during the past decade animal husbandry has declined due to disease, regional limitations, and a growing unwillingness to raise animals.

19. Rosstat, Rossiia v tsifrakh 2020 (Moscow: Rosstat, 2020), 356.

20. Dmitri Rylko, Irina Khramova, Vasilii Uzun, and Robert Jolly, 'Agroholdings: Russia's New Agricultural Operators', in Russia's Agriculture in Transition: Factor Markets and Constraints on Growth, ed. Zvi Lerman (Lanham, MD: Lexington Books, 2008), 95-133.

21. Oane Visser, Max Spoor, and Natalya Mamonova, 'Is Russia the Emerging Global "Breadbasket"? Recultivation, Agroholdings and Grain Production', Europe-Asia Studies 66, no. 10 (2014): 1589-1610.

22. See Stephen K. Wegren, Alexander M. Nikulin, and Irina Trotsuk, Food Policy and Food Security: Putting Food on the Russian Table (Lanham, MD: Lexington Books, 2018), 16-20.

23. Vasilii Uzun, Natalya Shagaida, and Zvi Lerman, 'Russian Agriculture: Growth and Institutional Challenges', Land Use Policy 83 (2019): 475487.

24. FAO, Russian Federation: Analysis of the Agribusiness Sector in Southern Russia (Rome: FAO, 2009); and David Epshtein, Konstantin Hahlbrock, and Jurgen Wandel, 'Why Are Agroholdings so Pervasive in Russia's 
Belgorod Oblast'? Evidence from Case Studies and Farm-Level Data', Post-Communist Economics 25, no. 1 (2013): 59-81.

25. Rylko, Khramova, Uzun, and Jolly, 'Agroholdings: Russia's New Agricultural Operators'; FAO, Russian Federation: Analysis of the Agribusiness Sector in Southern Russia; and V. Ia. Uzun and N. I. Shagaida, Agrariaia reforma $v$ postsovetskoi Rossii: mekhanizmy $i$ resul'taty (Moscow: Delo: 2015), 174-82.

26. V. Ia. Uzun and N. I. Shagaida, 'Razvitie sel'skogo khoziaistva: ot krupnogo importera do eksportera', in Ekonomicheskaia politika Rossii, eds. V. S. Gurevich et al. (Moscow: Delo, 2020), 427.

27. I. Davydova and J. R. Franks, 'The Rise of Large Farms: Why Agroholdings Dominate Russia's Agricultural Sector', Journal of the National Research University Higher School of Economics 24, no. 3 (2015): 133159.

28. E. A. Gataulina, V. Ia. Uzun, A. V. Petrikov, and R. G. Yanbykh, 'Vertical Integration in an Agroindustrial Complex: Agrofirms and Agroholdings in Russia', in The Dynamics of Vertical Coordination in Agrifood Chains in Eastern Europe and Central Asia, Case Studies, ed. Johan F. M. Swinnen, Working Paper no. 42 (Washington, DC: World Bank, 2005), 45-71; and Heinrich Hockmann, Raushan Bokusheva, and Irina Bezlepkina, 'Agroholding Membership: Does That Make a Difference in Performance?' Quarterly Journal of International Agriculture 48, no. 1 (2009): 25-46.

29. United States Department of Agriculture, Foreign Agriculture Service, 'Production, Supply and Demand Online Database'.

30. Olga Liefert, William M. Liefert, and Eric Luebehusen, 'Rising Grain Exports by the Former Soviet Union Region', Outlook Report WHS13A-01 (Washington, DC: Economic Research Service, USDA, 2013).

31. The close relationship between fluctuation in Russian annual grain production and exports shows how weather-driven downturns in output generate export volatility.

32. Suchada Langley, 'International Agriculture and Trade Reports. International Financial Crises and Agriculture', Report WRS-99-3 (Washington, DC: Economic Research Service, U.S. Dept. of Agriculture, 2000).

33. Unless otherwise identified, all data on changes in the ruble exchange rate are from or computed from ERS International Macroeconomic Database.

34. Trading Economics, 'Russia Inflation Rate', n.d. https://tradingecono mics.com/russia/inflation-cpi. Accessed 17 August 2020.

35. Tat'iana Kulistikova, 'Minsel'khoz razrabotal gosprogrammu vovlencheniia v oborot sel'khozzemel'. 9 January 2020. https:// www.agroinvestor.ru/analytics/news/33051-minselkhoz-razrabotal-gos programmu-vovlecheniya-v-oborot-selkhozzemel/. Accessed 8 October 2020 . 
36. Patrick Meyfroidt, Florian Schierhorn, Alexander V. Prishchepov, Daniel Müller, and Tobias Kuemmerle, 'Drivers, Constraints and Trade-offs Associated with Recultivating Abandoned Cropland in Russia, Ukraine and Kazakhstan', Global Environmental Change 37 (2016): 1-15.

37. Uzun et al., 'Prospects of the Farming Sector and Rural Development in View of Food Security'; and Liefert and Liefert, 'Russia's Potential to Increase Grain Production by Expanding Area', 505-523.

38. See Sergei Kiselev, Roman Romashkin, Gerald C. Nelson, Daniel MasonD'Croz, and Amanda Palazzo, 'Russia's Food Security and Climate Change: Looking into the Future', Economics E-Journal 7 (2013-39): $1-66$.

39. William M. Liefert and Olga Liefert, 'Changing Crop Area in the Former Soviet Union Region', Outlook Report FDS17b-01 (Washington, DC: Economic Research Service, USDA, 2017).

40. United States Department of Agriculture, Foreign Agriculture Service, 'Production, Supply and Demand Online Database'.

41. Peter Wehrheim, Klaus Frohberg, Eugenia Serova, and Joachim von Braun, eds. Russia's Agro-food Sector: Towards Truly Functioning Markets (Dordrecht, Netherlands: Kluwer Academic Publishers, 2000).

42. Stephen K. Wegren, Alexander M. Nikulin, and Irina Trotsuk, 'Russian Agriculture During Putin's Fourth Term: A SWOT Analysis', Post-Communist Economies 31, no. 4 (2019): 419-50.

43. Gokhberg, Kuzminov, Chulok, and Thurner, 'The Future of Russia's Agriculture and Food Industry Between Global Opportunities and Technological Restrictions'.

44. Simo Leppanen, Markku Ollikainen, and Liisa Saikkonen, 'Impact of Climate Change on CerealGrain Production in Russia', in Agricultural Goods and Bads: Essays on Agriculture and Environmental Externalities (Helsinki: University of Helsinki, 2019).

45. Maria Belyaeva and Raushan Bokusheva, 'Will Climate Change Benefit or Hurt Russian Grain Production? A Statistical Evidence from a Panel Approach', Climatic Change 149 (2018): 205-17.

46. U.S. Department of Agriculture, 'USDA Agricultural Projections to 2029', Long-term Projections Report OCE-2020-1 (Washington, DC: USDA, 2020).

47. Ibid.

48. V. V. Rau, 'Grain Market in Russia: From Crisis to Revival', Studies in Russian Economic Development 23, no. 1 (2012): 48-56. 


\section{Selected Bibliography}

Belyaeva, Maria and Raushan Bokusheva. 'Will Climate Change Benefit or Hurt Russian Grain Production? A Statistical Evidence from a Panel Approach'. Climatic Change 149 (2018): 205-17.

Bokusheva, Raushan, Heinrich Hockmann, and Subal C. Kumbhakar. 'Dynamics of Productivity and Technical Efficiency in Russian Agriculture'. European Review of Agricultural Economics 39, no. 4 (2011): 611-37.

Davydova, I. and J. R. Franks. 'The Rise of Large Farms: Why Agroholdings Dominate Russia's Agricultural Sector'. Journal of the National Research University Higher School of Economics 24, no. 3 (2015): 133-159.

Epshtein, David, Konstantin Hahlbrock, and Jurgen Wandel. 'Why Are Agroholdings so Pervasive in Russia's "Belgorod Oblast"? Evidence from Case Studies and Farm-level Data'. Post-Communist Economics 25, no. 1 (2013): 59-81.

Food and Agriculture Organization (FAO). Russian Federation: Analysis of the Agribusiness Sector in Southern Russia. Rome: FAO, 2009.

Gataulina, E. A., V. Ia. Uzun, A. V. Petrikov and R. G. Yanbykh. 'Vertical Integration in an Agroindustrial Complex: Agrofirms and Agroholdings in Russia'. In The Dynamics of Vertical Coordination in Agrifood Chains in Eastern Europe and Central Asia, Case Studies, ed. Johan F.M. Swinnen. Working Paper No. 42. Washington, DC: World Bank, 2005, 45-71.

Gokhberg, L., I. Kuzminov, A. Chulok, and T. Thurner. 'The Future of Russia's Agriculture and Food Industry Between Global Opportunities and Technological Restrictions'. International Journal of Agricultural Sustainability 15, no. 4 (2017): 457-466.

Hockmann, Heinrich, Raushan Bokusheva, and Irina Bezlepkina. 'Agroholding Membership:Does that Make a Difference in Performance?' Quarterly Journal of International Agriculture 48, no. 1 (2009): 25-46.

Kiselev, Sergei, Roman Romashkin, Gerald C. Nelson, Daniel Mason-D'Croz and Amanda Palazzo. 'Russia's Food Security and Climate Change: Looking into the Future'. Economics E-Journal 7 (2013-39): 1-66.

Kuzminov, Ilya, Leonid Gokhberg, Thomas Thurner, and Elena Khabirova. 'The Current State of the Russian Agricultural Sector'. EuroChoices 17, no. 1 (2018): 52-57.

Langley, Suchada (ed.). 'International Agriculture and Trade Reports. International Financial Crises and Agriculture'. Report WRS-99-3. Washington, DC: Economic Research Service, U.S. Dept. of Agriculture, 2000.

Leppänen, Simo, Liisa Saikkonen, and Markku Ollikainen. 'Impact of Climate Change on Cereal Grain Production in Russia'. In Agricultural Goods and Bads: Essays on Agriculture and Environmental Externalities. Helsinki: University of Helsinki, 2019. 
Liefert, William M. 'Comparative (Dis?) Advantage in Russian Agriculture'. American Journal of Agricultural Economics 84, no. 3 (2002): 762-767.

Liefert, William M. and Johan Swinnen. 'Changes in Agricultural Markets in Transition Economies’. Agricultural Economic Report No. 806. Washington, DC: Economic Research Service, USDA, 2002.

Liefert, William M. and Olga Liefert. 'Russian Agriculture During Transition: Performance, Global Impact, and Outlook'. Applied Economic Perspectives and Policy 34, no. 1 (2012): 37-75.

Liefert, William M. and Olga Liefert. 'Russia's Potential to Increase Grain Production by Expanding Area'. Eurasian Geography and Economics 56, no. 5 (2015): 505-523.

Liefert, William M. and Olga Liefert. 'Changing Crop Area in the Former Soviet Union Region'. Outlook Report FDS17b-01. Washington, DC: Economic Research Service, U.S. Dept. of Agriculture, 2017.

Liefert, William M. and Olga Liefert. 'Russian Agricultural Trade and World Markets'. Russian Journal of Economics 6, no. 1 (2020): 56-70.

Liefert, Olga, William M. Liefert, and Eric Luebehusen. 'Rising Grain Exports by the Former Soviet Union Region'. Outlook Report WHS-13A-01. Washington, DC: Economic Research Service, U.S. Dept. of Agriculture, 2013.

Meyfroidt, Patrick, Florian Schierhorn, Alexander V. Prishchepov, Daniel Müller, and Tobias Kuemmerle. 'Drivers, Constraints and Trade-offs Associated with Recultivating Abandoned Cropland in Russia, Ukraine and Kazakhstan'. Global Environmental Change 37 (2016): 1-15.

Rada, Nicholas, William M. Liefert, and Olga Liefert. Productivity Growth and the Revival of Russian Agriculture. Economic Research Report no. 228. Washington, DC: Economic Research Service, U.S. Dept. of Agriculture, 2017.

Rau, V. V. 'Grain Market in Russia: From Crisis to Revival'. Studies in Russian Economic Development 23, no. 1 (2012): 48-56.

Rosstat. Rossiia v tsifrakh 2020. Moscow: Rosstat.

Rylko, Dmitri, Irina Khramova, Vasilii Uzun, and Robert Jolly. 'Agroholdings: Russia's New Agricultural Operators'. In Russia's Agriculture in Transition: Factor Markets and Constraints on Growth, ed. Zvi Lerman. Lanham, MD: Lexington Books, 2008, 95-133.

Shagaida, Natalya and Zvi Lerman. 'Land Reform and Development of Land Markets'. In Russia's Agriculture in Transition: Factor Markets and Constraints on Growth, ed. Zvi Lerman. Lanham, MD: Lexington Books, 2008, 137-183.

Swinnen, Johan F. M., Kristine Van Herck and Liesbet Vranken. 'Agricultural Productivity Paths in Central and Eastern European Countries and the Former Soviet Union: The Role of Reforms, Initial Conditions and Induced 
Technological Change'. In Productivity Growth in Agriculture: An International Perspective, eds. Keith O. Fuglie, Sun Ling Wang, and V. Eldon Ball. Oxfordshire, UK: CABI International, 2012, 127-44.

U. S. Department of Agriculture. 'USDA Agricultural Projections to 2029'. Long-term Projections Report OCE-2020-1. Washington, DC: USDA, 2020.

Uzun, V. Ia. and N. I. Shagaida. 'Razvitie sel'skogo khoziaistva: ot krupnogo importera do eksportera.' In Ekonomicheskaia politika Rossii, eds. V. S. Gurevich et al. Moscow: Delo, 2020.

Uzun, V. Ia. and N. I. Shagaida. Agrariaia reforma $v$ postsovetskoi Rossii: mekhanizmy $i$ resul'taty. Moscow: Delo, 2015.

Uzun, Vasilii, Natalya Shagaida, and Zvi Lerman. 'Russian Agriculture: Growth and Institutional Challenges'. Land Use Policy 83 (2019): 475-487.

Uzun, Vasilii, Valery Saraikin, Ekaterina Gataulina, Natalya Shagayda, Renata Yanbykh, Sebastien Mary, and Sergio Gomez y Paloma. 'Prospects of the Farming Sector and Rural Development in View of Food Security: The Case of the Russian Federation'. Luxembourg: European Commission, 2014.

Visser, Oane, Max Spoor, and Natalia Mamonova. 'Is Russia the Emerging Global 'Breadbasket'? Recultivation, Agroholdings and Grain Production'. Europe-Asia Studies 66, no. 10 (2014): 1589-1610.

Wegren, Stephen K. 'Land Reform in Russia: What Went Wrong?' Post-Soviet Affairs 24, no. 2 (2008): 121-147.

Wegren, Stephen K., Alexander M. Nikulin and Irina Trotsuk. 'Russian Agriculture during Putin's Fourth Term: A SWOT Analysis'. Post-Communist Economies 31, no. 4 (2019): 419-50.

Wegren, Stephen K., Alexander M. Nikulin, and Irina Trotsuk. Food Policy and Food Security: Putting Food on the Russian Table. Lanham, MD: Lexington Books, 2018.

Wehrheim, Peter, Klaus Frohberg, Eugenia Serova, and Joachim von Braun, eds. Russia's Agro-food Sector: Towards Truly Functioning Markets. Dordrecht, Netherlands: Kluwer Academic Publishers, 2000. 
Open Access This chapter is licensed under the terms of the Creative Commons Attribution 4.0 International License (http://creativecommons.org/licenses/ by $/ 4.0 /$ ), which permits use, sharing, adaptation, distribution and reproduction in any medium or format, as long as you give appropriate credit to the original author(s) and the source, provide a link to the Creative Commons license and indicate if changes were made.

The images or other third party material in this chapter are included in the chapter's Creative Commons license, unless indicated otherwise in a credit line to the material. If material is not included in the chapter's Creative Commons license and your intended use is not permitted by statutory regulation or exceeds the permitted use, you will need to obtain permission directly from the copyright holder.

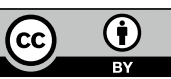

